\title{
ミツユビカモメとオオミズナギドリの 大量擎死と渡りに対する考察
}

風間辰夫

\section{Summary}

\section{On the mass destruction of Rissa triductyla and Calonectris leucomelas and their migration at Kashiwazaki, Niigata Prefecture}

\author{
Tatsuo Kazama
}

Kashiwazaki coast on Japan Sea side in Niigata Prefecture is known as a place where sea birds (also fishes and turtles) are washed ashore and land bird migrants are disturbed. This is due to the particular position of this town, with Sado I. at $60 \mathrm{~km}$ offshore and surrounded by mountains behind. In March 1965 about 500 Rissa tridactyla were seen from the shore and 150 (or more) dead birds (of which 80\% were young) were collected during 23-31 March by 5 persons and the auther examined 12 우 우 $4 \hat{\delta} \delta$, were found during March 1 unsexed. Sixteen Calonectris leucomelas, 12 우우 $4 \hat{\delta}$ 송, were found during March and April 1965 and on each in 1962 and 1964. This species is observed migrating offshore during towards north in this season. Dead birds are found after strong weather and have empty stomachs and their feathers are often spoiled by ship oil. Notes on local weather conditions are given.

\section{まえがき}

1958年 4 月加ら現在まで秥崎市と刈羽郡で，獘死鳥の調査在しているが，市 でに拾得した死体は 300 個体余に及んで招り，冬島孛中心にした海鳥が大部分 である。

柏䐀海岸は新渴罢のほぼ央部に位置して，全長 $29.4 \mathrm{~km}$ ，対岸の俗渡ケ島 とは60 km を隔だて，背後には米山 $(993 \mathrm{~m})$ ，黑姫山 $(889 \mathrm{~m})$ ，八石山 $(517 \mathrm{~m})$ があり自然の環境にはめぐまれている。またこの地域は植物，昆虫類の程類も 量も紧内では獃富で, 珍らしい種類孔発見されている。鳥類についても, 多く 
の渡り鳥が，柏崎，㺫羽地方を通過するものと推定される。例えば，ウミスズ メ科の 8 種類, シギ類の15種類，その他迷岛としてはシロ八ラミズナギドリ， ヤツガシラ(十羽元一による), オオヒバリ，チョウセンオオタカ(岡堇高によ る)、ツシマヤマガラ,マキノセンニュウ等を確認している。

整死鳥が漂着する場所は圂浜から悪田までの間約 $5 \mathrm{~km}$ と, 宮川, 荒浜の海 岸のごく一部で，他の海岸ではほとんど発見されていない。

1965年の1月〜4月に従来にみられない多数の酰死体力溌睍されたので， それについて報告する。

\section{拾得した獘死鳥}

(1) ミッュビカモメ Rissa tridactyla pollicaris

この種は主として太平洋側に，多くは冬鳥として渡来するということであ り，新湿県下では1961に早1 羽力記録されているだけだが，ての後著者の調查 によって，柏崎裹浜海岸へ打上げら机た䇟死体は（闭翼と胸部のみのbのだ の束集数えた）次のと扣り多数の個体に及んでいる

\begin{tabular}{|c|c|c|c|c|c|}
\hline 年 & 月 & $\boxminus$ & 老紀 & 性 & 備考 \\
\hline 1962 & 2 & 16 & 站 & 性不明 & \\
\hline 1965, & 3 & 23 & 成 & 今 & (Fig. 1) \\
\hline$"$ & & " & 幼 & 오 & \\
\hline$"$ & & $"$ & 纤 & 우 & \\
\hline$"$ & & $"$ & 㭃 & 우 & \\
\hline " & & $"$ & 幼 & 오 & \\
\hline$"$ & & " & 幼 & 우 & \\
\hline 1965 & 3 & 26 & 成 & 우 & (Fig. 2) \\
\hline " & & " & 糼 & $\hat{0}$ & \\
\hline$"$ & & " & 动 & 우 & \\
\hline$"$ & & $"$ & 好 & $\delta$ & \\
\hline " & & " & 期 & 우 & \\
\hline 1965 , & 3 & 28 & 奻 & 우 & (Fig. 3) \\
\hline$"$ & & " & 奻 & P & \\
\hline " & & $"$ & 约 & 우 & \\
\hline " & & " & 纤 & $\widehat{b}$ & \\
\hline$"$ & & $"$ & 幼 & 우 & \\
\hline & & & & & \\
\hline
\end{tabular}




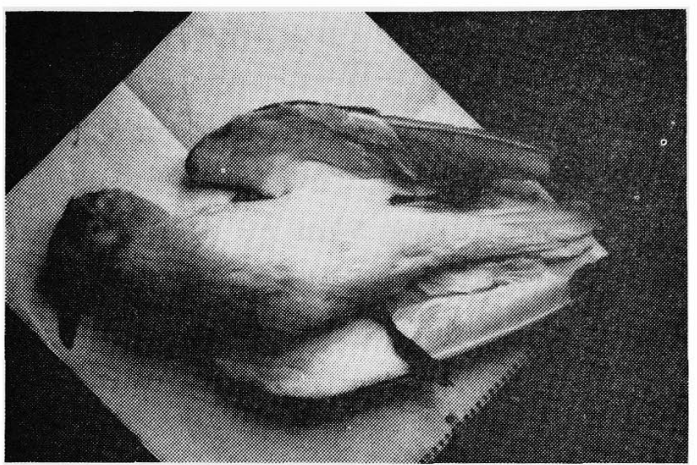

Fig. 1. Rissa tridactyla $\hat{\circ}$ ad.

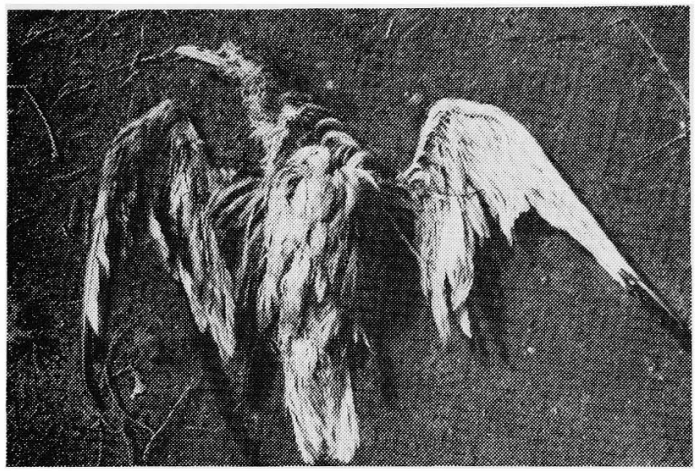

Fig. 2. Rissa tridactyla 우 ad.

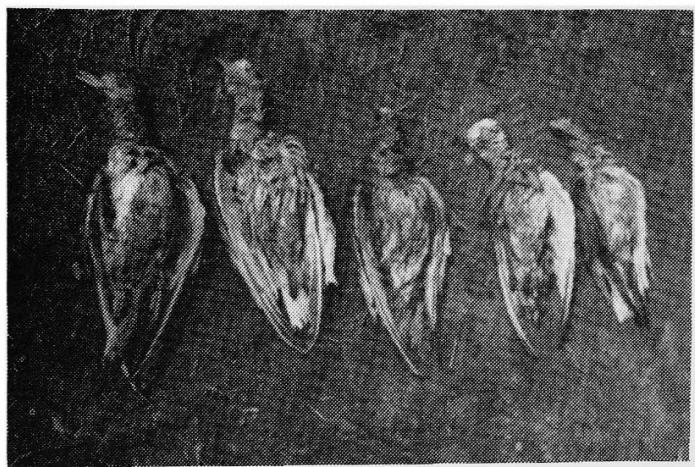

Fig. 3. Rissa tridactyla juv.
1965年度の場合には，獘 死体は柏崎少午愛鳥クラブ 員 5 人が， 3 月 23 日加ら 3 月31日までに拾得したもの で約 150 体で，その後も， 数多く拾得して来た。した がって䌘死体は200 羽はあ ったと推量される。このこ ろ柏崎刯浜海岸附近への飛 来数は約 500 羽であり，そ のうちの約 $80 \%$ 幼鳥と認 められた（その他ほぼ完全 ではあるが, 性不明 8 , 雄 2 がある)。

(2) オオミズナギドリ Calcnectris leucomelas

この種は怕崎と佐渡の間 の海上を例年 2 月末頃から 4 月に 100 羽〜300羽の群が 北上しているのを観察して いる（1964 年 2 月 16 日裹 浜，約 100 羽，1965年 3 月 20 日裏浜, 約 150 羽, など の観察がある)。柏崎, 㺫 羽の殆んどの小学校にこの 種の標本があり（製作者は 全部力モメとしている）調 査した結果昭和年間に寄附 されたものであることが判 明した。枯崎海岸を渡りの さい通過するのは, 突発的 ではないことが明らかであ る。拾得したものは次のと 
おりである。

\begin{tabular}{|c|c|c|c|c|c|}
\hline 年 & 月 & 日 & 老㭃 & 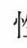 & 備考 \\
\hline 1962, & 3 , & 18 & 成 & & (Fig. 4) \\
\hline 1964, & 3 , & 4 & 成 & & \\
\hline 1965, & 3 , & 21 & 成 & & \\
\hline 1965, & 4, & 2 & 成 & & \\
\hline 1965, & 4 & 6 & 成 & & \\
\hline 1965, & 4 & 12 & 成 & & \\
\hline$"$ & & " & 成 & & \\
\hline " & & " & 成 & & (Fig. 5) \\
\hline " & & " & 成 & & \\
\hline " & & " & 成 & & \\
\hline " & & "I & 成 & & \\
\hline " & & " & 成 & & \\
\hline " & & " & 成 & & \\
\hline " & & " & 成 & & \\
\hline " & & "I & 成 & & \\
\hline 1965, & 4 , & 25 & 成 & & \\
\hline
\end{tabular}

\section{獘死鳥体の検討結果}

拾得鳥の $80 \%$ は羽元一 氏に解剖をお願いした。同 氏によれば，餓死が主因と のことであるが，残り $20 \%$ を筆者が解剖してみると同 様，餓死であることが判明 した。

餓死の原因は，風雪力強 く, 風速 $15 \mathrm{~m} / \mathrm{sec}$. 超える と鳥類は思うように飛べ

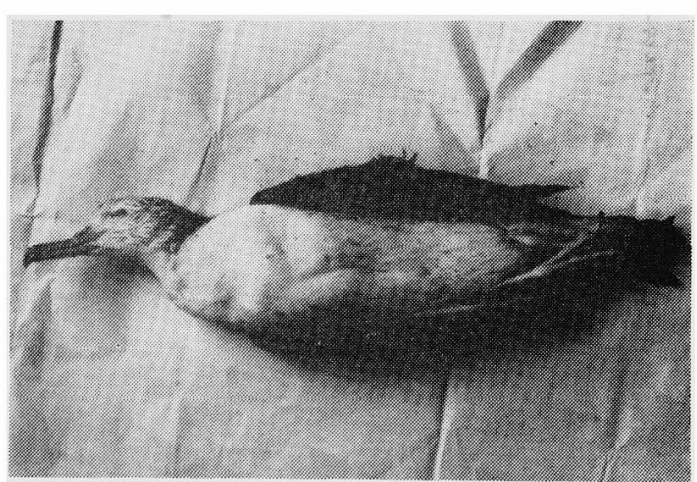

Fig. 4. Calonectris leucomelas 우 ad. ず，写真 (Fig. 6) のように海岸附近のものは，かろうじて何かを食べている が，海上の個体は風のために海岸えよりつくことが出来ず，餌を求めて海上を さまよい疲労のため落鳥するものと思われる。総数 300 個体を超えると思われ るミツユビカモメが，䄸崎海上附近で落鳥したことを考えてみれば，この地域 


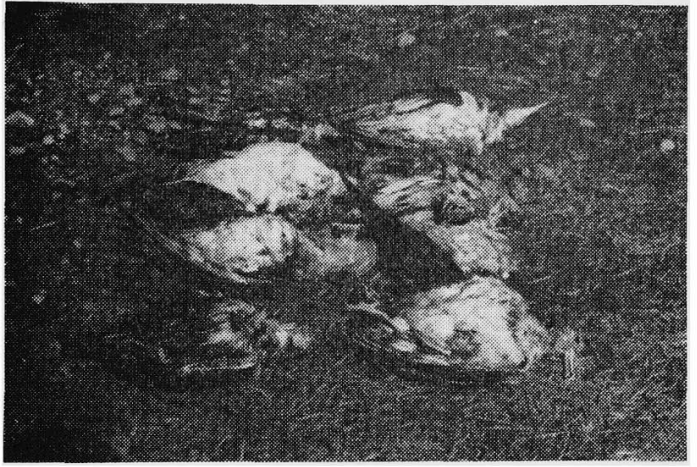

Fig. 5. Rissa tridactyla and Calonectris leucomelas.

は気象条件が急変するよう な渡り鳥にとっては不利な 状況にあるのではないかと 思う。拾得した鳥の死体の 解剖結果から次のようなこ とが解った。

(1) 体が非常にやせてい る。

（2）重油が附着している (船加与流古重油)。

(3) 砂が多く附着している （落鳥後波にもまれたた めと思われる)。

（4）腐敗度は個体によって差が多い（強風でないと海岸へ漂着しないので海水 中に浸漬している時間的のずれが生ずるためと思う)。

(5) 筋肉に塩分が浸透していない（海水に浸漬していた時間が短かいためで,

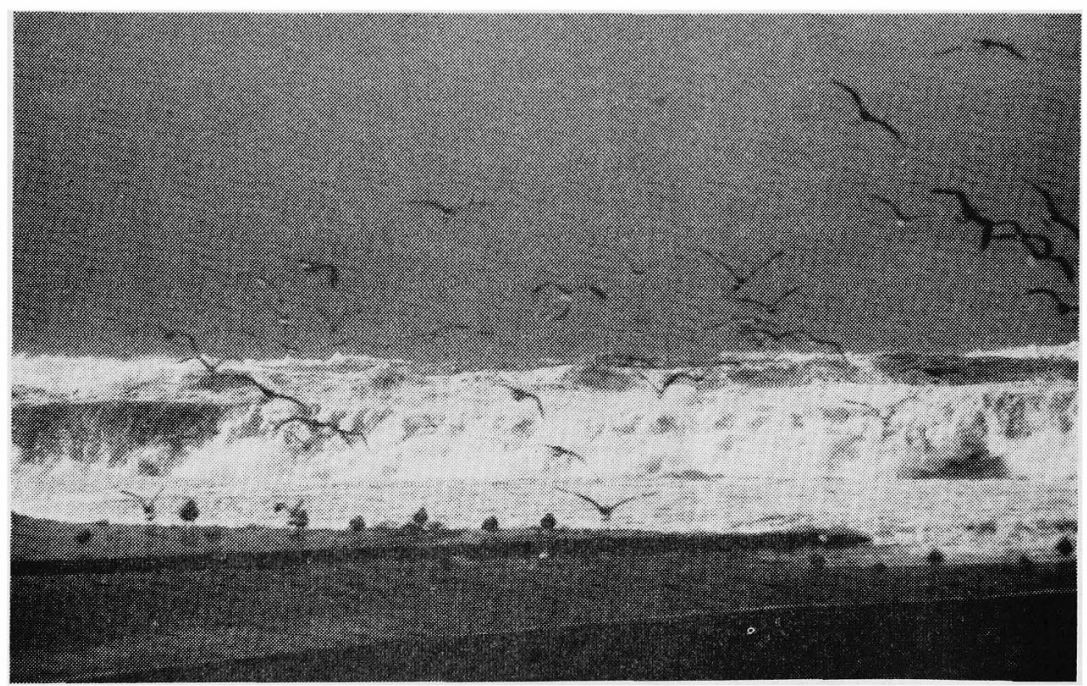

Fig. 6. 強風と高潮により，海岸へ避難しているミツユビカモメの群 A keim of Rissa tryductyla refuge to coast for wind-storm (Kashiwazaki coast on Japan Sea side in Niigata Pref.) 
梢崎近海で落鳥たといえる)。

(6) 内淢についてい殆んど損傷がない。

（7）外傷はあるが，生活反応が涩められないので落鳥したあと，漂流物と衝突 して出来た多のと思引。

\section{気象と海況から見た考察}

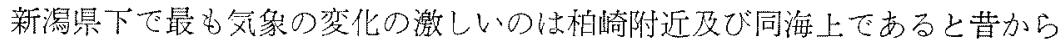
い伝えられて扣り，冬期間（11月～翌年3月まで）強風波浪注意（風䉕も含 む）報は新潟気象台発表によれば25回（1964年11月〜1965 年3月）であった が，枮崎ではこれ以上すなわち，3日に1回のわりあいで，風雪波浪がやって 米る。鳥が落鳥するのは，北，ないし北西の強風の時であると思う。その証拠 として笺者の調査した範囲内（7年間）では北西の風（風速 $15 \mathrm{~m} / \mathrm{sec}$ 以上） の日でなければほとんど漂蕒物を拾得することは出来ないことから見てもわか る。例文ば1965年4月10日に新潟気象台の発表によれば，強風，波浪注意報， 北西の風强く海上では $15 \mathrm{~m} / \mathrm{sec}$ 以上，4月11日まてつうくとあり，その後日 4 月14日にオオミズナギドリ10羽，ミッュビカモメ2羽の拾得をしている。ま たこの海岸約 $2.5 \mathrm{~km}$ 快，鳥類死体の漂着があるたけではなく，人間の溺死体 女漂着する(柏崎警察署による)。さらに，材木，鳥類，㿞類，アザラシ，とく に過去 7 年間ては象類が多い。アカウミガメなど10体，またニホンザルが1頭 ある。漂着については次のことがいえると思う。

（1）風は北西の風か，北の風であるが，北西の風 $15 \mathrm{~m} / \mathrm{sec}$ 以上の場合

(2) 海岸線の構造少らくる。

(3) 鯨波，青梅川，東三輸海岸は断崖である。

\section{ま と $\varnothing$}

今回の落鳥漂着鳥死体の調査から，オオミズナギドリは，北上して繁殖地へ 向う途中のbので，移動時期が，2月〜4月たあると想像できる。ミッユビカ モメはこれまで飛来か確認されていないのは，海上生活を主とするため陸地に 近接することが少なかったためであろう。柏崎海上走通過する鳥類（海烏）の

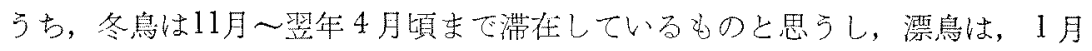
〜4月の間に移動するものと思放れる。また倠，雄克比較した場合オ才ミズナ

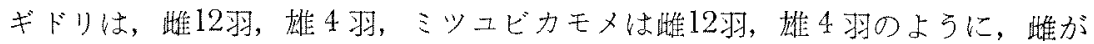
多い。また陸鳥での場合はこれと逆に雄の獘死が多いのである。これは，李節

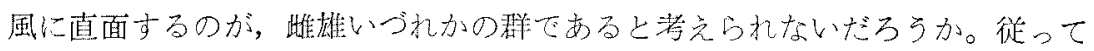
渡りのさいは，蜼は雌，雄は崔で策団在維んているように推理される。ミッב 


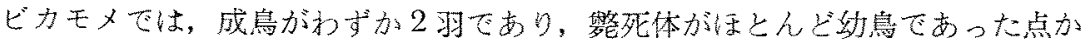

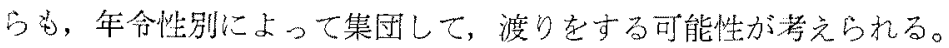

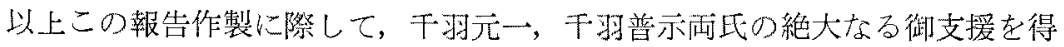
たのでここに厚く感謝の意を表する。

東京都内ならびに近県で拾得さ玌た

ッルクイナ Gallicrex cinerea

1966年10月から11月の間に東京都内と近县でツクルイナが拾得された。殁しい現象な ので表示して報告して执く。

\begin{tabular}{|c|c|c|c|c|c|}
\hline No. & 埜 & 繁 命 & 铪得日 & 拾 得 場 所 & 僙 \\
\hline 1 & $?$ & $?$ & $10-5$ & $?$ & 上野動物園に収空（亡死） \\
\hline 2 & 우 & 牥望 & $10-13$ & 目黑区 & 死体て取容 \\
\hline 3 & q & 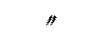 & $10-14$ & 㫛川IX & 生科(慨育中) \\
\hline 4 & 分 & 成鳥 & $10-15$ & 大曰网 & $" \prime("))$ \\
\hline 5 & $?$ & $?$ & $10 \rightarrow 16$ & $?$ & 井の䫓公園(死做) \\
\hline 6 & 足 & 成点 & $10-17$ & 中块区 & 死体で収签 \\
\hline 7 & q & 奻囦？ & $10-18$ & 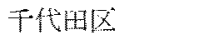 & $"$ \\
\hline 8 & $?$ & $?$ & $10-18$ & 埼王是户由日 & 上野動物圊で飼索中 \\
\hline 9 & 우 & 成鳥 & $10-18$ & 品川区 & 収窘後死亡 \\
\hline 10 & $\hat{\beta}$ & " & $10-18$ & 中央区 & 㱠体て取容 \\
\hline 11 & $?$ & $?$ & $10-18$ & ? & 上野陲物園で搷苚中 \\
\hline 12 & $?$ & 幼鳥 & $10-22$ & 板橋区 & " \\
\hline 13 & 우 ? & " & $11-4$ & $?$ & 抹の頭公園で飼䟫中 \\
\hline 14 & $?$ & $?$ & $11-16$ & 些由谷区 & 放傁 \\
\hline
\end{tabular}

霝 考

（i）表の中で飼育所の明示してい索いのは林萦試娩場で飼育している。

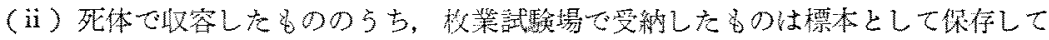
ある。

(iii）世田ケ谷区で放舁したのは，野島の会会圆の原喜久雄区肪確認している。

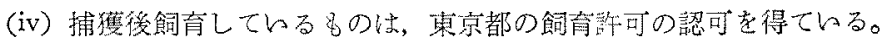

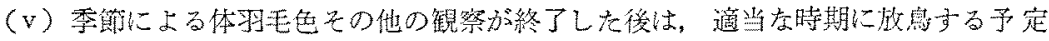
飞方。

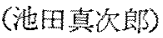

